\title{
UNITY OR DIVERSITY IN WISDOM THEOLOGY? A CANONICAL AND COVENANTAL PERSPECTIVE ${ }^{1}$
}

\author{
Richard L. Schultz
}

\begin{abstract}
Summary
Recent publications on Old Testament wisdom literature perpetuate the theory of $a$ 'crisis in wisdom' and leave unresolved the question of its provenance within Old Testament theology. Despite considerable diversity within the zuisdom corpus, Proverbs, Ecclesiastes, and Job are in basic agreement regarding zvisdom's limitations and benefits, as well as regarding divine freedom and retribution. Thus a case can be made for unity in wisdom theology, a theology which is rooted in Israel's covenant faith and in its creation traditions. The intertextual relationships between the wisdom corpus and the other Old Testament books indicate that this tradition has been consciously integrated into the larger Old Testament canon.
\end{abstract}

\section{Introduction: The Nature of the Problem}

While in Germany, the following proverb caught my attention: 'Lieber heimlich schlau als unheimlich blöd.'(Better privately clever than publicly stupid.) Such secular home-spun wisdom conceivably could be found in the Old Testament proverbial collections, for it is strikingly similar to Proverbs 12:23 or 17:28. However, it seems to have little in common with the law that thunders from Sinai or the prophetic voice that boldly proclaims: 'Thus says the LORD...'

\footnotetext{
1 This essay is a revision of the 1996 Tyndale Old Testament Lecture delivered on July 9, 1996, at Tyndale House, Cambridge, England. The lecture was inspired by David Hubbard's 1965 Tyndale Old Testament Lecture, 'The Wisdom Movement and Israel's Covenant Faith', TB 17 (1966) 3-33, and seeks to develop more fully some of the lines of connection which he suggested.
} 
Some scholars claim that proverbial wisdom supports a theology which functions similarly to a vending machine: insert wise behaviour in the coin slot, pull the lever, and prosperity will tumble down into the tray for easy retrieval. Even if it is conceded that this theology is a distant cousin of the covenantal pattern of blessings and curses, this optimistic theology usually is presented as having been sent reeling by Job's intense sufferings and Qoheleth's cynical observations. Accordingly, most contemporary scholars consider it difficult to integrate Old Testament wisdom theology into Old Testament theology as a whole, viewing its traditions as too unique and too diverse to make this feasible.

This assessment has not caused the wisdom corpus to be neglected. Instead, 'the rehabilitation of Israelite wisdom has been one of the more significant developments in Old Testament scholarship in the last third of the 20th century.' 2 However, recent publications indicate that a consensus has yet to emerge regarding the theological provenance of Old Testament wisdom. On the one hand, Clements emphasizes wisdom's role as an intellectual tradition, promoted for its functional usefulness within the monarchical state but still useful after the exile because of its original educational role and its lack of national covenantal presuppositions. Clements focuses on the 'fear of the LORD' as theologically foundational to wisdom while downplaying creation. On the other hand, Perdue concludes: 'Each of the wisdom texts finds its

2J. Day, R.P. Gordon, and H.G.M. Williamson (eds.), Wisdom in Ancient Israel. Essays in honour of J.A. Emerton (Cambridge: CUP, 1995) 1. Other major contributions on Israelite wisdom which have appeared in English since 1990 include J.G. Gammie, and L.G. Perdue (eds.), The Sage in Israel and the Ancient Near East (Winona Lake: Eisenbrauns, 1990; R.E. Clements, Wisdom in Theology (Grand Rapids: Eerdmans, 1992); S. Weeks, Early Israelite Wisdom (Oxford: Clarendon, 1994); L.G. Perdue, Wisdom $\mathcal{E}$ Creation. The Theology of Wisdom Literature (Nashville: Abingdon, 1994); J. Blenkinsopp, Sage, Priest, Prophet. Religious and Intellectual Leadership in Ancient Israel (Louisville: Westminster/John Knox, 1995); R.E. Murphy, The Tree of Life. An Exploration of Biblical Wisdom Literature (New York: Doubleday, 1996). Murphy, ibid., ix, speaks similarly of the recent 'rediscovery' of the biblical wisdom literature. 
theological center in creation.'3 Murphy, who previously characterized wisdom as a 'search for the order' inherent in creation, now speaks of the effort to impose order on the chaos of human experience. According to Murphy, divine revelation in wisdom is to be understood apart from the historical mode (salvation history) in that a dialogue with divinity 'takes place essentially via human experience and creation.' According to Steiert, on the contrary, wisdom can be understood legitimately only within the context of, and in relation to the specific elements of, the Yahwistic faith. 4

Equally disputed, as an understandable consequence of the lack of agreement regarding the essence of wisdom theology, is its place within Old Testament theology as a whole, which, as Reventlow correctly concludes, 'remains a still unresolved task for the future to deal with.' 5 Clements notes that, no matter what central structuring concept one chooses for Old Testament theology, 'wisdom is forced to appear at the periphery', being described as an 'errant child' or 'an orphan in the biblical household'. 6 Wisdom literature's apparent lack of reference to Israel's salvation history and to the characteristic elements of Yahwism has resulted in the much-rehearsed neglect of wisdom in twentieth-century syntheses of Old Testament theology.7 Von Rad remedied the marginalisation of wisdom in his two-volume Old Testament Theology with his final work, Wisdom in Israel, but presented wisdom as an independent tradition alongside historical and prophetic

${ }^{3}$ Clements, 'Wisdom and Old Testament Theology' in Wisdom in Ancient Israel, 273; Perdue, Wisdom \& Creation, 340.

${ }^{4}$ Murphy, The Tree of Life, 126, cf. 115-18; F.-J. Steiert, Die Weisheit Israelsein Fremdkörper im Alten Testament? Eine Untersuchung zum Buch der Sprïche auf dem Hintergrund der ägyptischen Weisheitslehren (Freiburg: Herder, 1990) 309.

${ }^{5}$ H.G. Reventlow, Problems of Old Testament Theology in the Twentieth Century (Philadelphia: Fortress, 1985) 184.

'Clements, 'Wisdom and Old Testament Theology', 270; Murphy, 'Wisdom Literature and Biblical Theology', BTB 24 (1994) 4; J.L. Crenshaw, 'Prolegomena' in Crenshaw (ed.), Studies in Ancient Israelite Wisdom (New York: Ktav, 1976) 1.

7See the recent survey by C.H. Scobie, 'The Place of Wisdom in Biblical Theology', BTB 14 (1984) 43-44. 
traditions, a dominant viewpoint even today, as exemplified by Childs who speaks of 'the wisdom tradition' in his recent biblical theology. 8

Preuß goes much further, rejecting Old Testament wisdom literature as 'heathen thought which must be denied a place not only within Christian theology but also within Old Testament theology as well. ${ }^{9}$ It would be easy to dismiss the matter as simply an academic debate, but there are practical ramifications as well. Westermann concludes:

One is generally convinced that wisdom texts are unsuited for preaching, religious education, counselling, or liturgy... Perhaps one is unconcerned with wisdom's significance for practical theology because it also has little or no significance for theology as well. ${ }^{10}$

Lux sums up the situation in the German church aptly by labelling the Old Testament wisdom corpus: 'the unpreached Bible'.11

The purpose of this essay is to take some initial steps toward remedying this situation by addressing two issues: (1) Is there, despite undeniable diversity, a fundamental unity within wisdom theology? (2) What are the theological roots of wisdom literature and do they suggest that wisdom theology is integrally related to Old Testament theology as a whole? In our examination of these issues, we will limit ourselves to Proverbs,

8Von Rad, Wisdom in Israel (Nashville: Abingdon, 1972; German ed. 1970); B.S. Childs, Biblical Theology of the Old and New Testaments. Theological Reflection on the Christian Bible (Minneapolis: Fortress, 1992) 187.

${ }^{9}$ H.-D. Preuß, 'Alttestamentliche Weisheit in christlicher Predigt?' in C. Brekelmans (ed.) Questions disputées de l'Ancien Testament. Méthode et théologie (BETL 33; Leuven: Leuven UP, 1974) 165-81.

${ }^{10} \mathrm{C}$. Westermann, 'Weisheit und praktische Theologie', Pastoraltheologie 79 (1990) 515.

${ }^{11}$ R. Lux, "'Die ungepredigte Bibel." Überlegungen zum theologischen Ort der Weisheit Israels in der christlichen Verkündigung', Pastoraltheologie 79 (1990) 524-44. In the American church, however, following two decades of a widely-proclaimed 'health and wealth' gospel, one perhaps should rather speak of Old Testament wisdom as 'the abused Bible'; $c f$. E. Achtemeier, Preaching from the Old Testament (Louisville: Westminster/ John Knox, 1989) 170-73; W.C. Kaiser, Jr., 'The Old Testament promise of material blessings and the contemporary believer', TJ 9 (1988) 151-70. 
Ecclesiastes and Job since these books are viewed most universally as belonging to the wisdom corpus. ${ }^{12}$

\section{The Unity of Wisdom Theology: a Canonical Perspective}

Contemporary discussions of biblical theology frequently address the problem posed by the theological diversity to be found within the biblical literature. ${ }^{13}$ Texts arising at different times, produced by different authors and editors representing different theological traditions, employing different literary genres to address different subjects with different emphases are bound to produce a diverse literature. Furthermore, as Goldingay has reminded us, such diversity is not inherently problematic but, rather, can be enriching, helping us to use the Old Testament theologically. ${ }^{14}$

In the case of the Old Testament wisdom corpus, we have in Proverbs a logically developed instructional (introductory) section followed by several proverbial collections in which ordering principles can be discerned though they are not immediately apparent. Qoheleth's quasiautobiographic wisdom treatise emphasizes the wide-spread frustrations and inequities of life which primarily are observed rather than experienced, while Job presents the intense but

\footnotetext{
12Job's inclusion has been questioned by some, Westermann, for example, describing it as a 'dramatised lament' (Der Aufbau des Buches Hiob [Stuttgart: Calwer, 1977] 27-39); cf. the discussion in J.L. Crenshaw, Old Testamemt Wisdom (Atlanta: John Knox, 1981) 16. However, Murphy ('Wisdom Theology and Biblical Theology',4) speaks of these as 'three unquestionable wisdom books', though both Murphy, The Tree of Life, and Perdue, Wisdom $\mathcal{E}$ Creation, also discuss the apocryphal books of Ben Sira and the Wisdom of Solomon.

${ }^{13}$ See J. Goldingay, 'Diversity and Unity in Old Testament Theology', VT 34 (1984) 153-68; idem, Theological Diversity and the Authority of the Old Testament (Grand Rapids: Eerdmans, 1987); J.G. McConville, 'Using Scripture for Theology: Unity and Diversity in Old Testament Theology', Scottish Bulletin of Evangelical Theology 5 (1987) 39-57; C. Vang, “'Der HERR ist einer!" Von der Einheit und der Verschiedenheit in der Theologie des Alten Testaments', EuroJTh 4 (1995) 145-59.

${ }^{1+}$ Goldingay, 'Diversity and Unity in Old Testament Theology', 159.
} 
innocent suffering experienced by an individual in debate with his critics. The resultant diversity is reflected in the differing lengths, cogency, and styles in these books and even in their very different treatment of the creation theme. However, most scholars would claim that the type of theological diversity found in the Old Testament wisdom literature is anything but complementary or mutually enriching. Instead, the scepticism, pessimism, even cynicism or nihilism of Qoheleth's and Job's broken worlds are set against the rosy-eyed optimism of Proverbs' tidy world. Various terms have been used to characterize this relationship: 'attack' (Genung), 'crisis' (Gese, Schmid, O. Kaiser), 'breakdown' (Preuß), 'protest' (Goldingay), 'dissent' (Crenshaw) or, more mildly, 'reformation' (Spina), or even (euphemistically) 'wisdom in dialogue' (Murphy), but never 'mere diversity'. 15

Underlying most approaches is the attitude expressed so well by Hubbard in his earlier Tyndale Lecture and approvingly quoted by Goldingay: 'Proverbs seems to say, "These are the rules for life; try them and find that they will work." Job and Ecclesiastes say, "We did, and they don't."'16 The question that we would like to ask is: is it really the case

15J.R. Genung, The Hebrew Literature of Wisdom in the Light of To-Day. A Synthesis (Boston: Houghton Mifflin, 1906)-according to Genung, Job represents 'the attack by the centre' while Ecclesiastes represents 'the attack by the flank'; H. Gese, 'Die Krisis der Weisheit bei Koheleth' in Les Sagesses du Proche-Orient Ancien (Paris: Presses Universitaires, 1963) 13951; H.H. Schmid, Wesen und Geschichte der Weisheit - eine Untersuchung zur altorientalischen und israelitischen Weisheitsliteratur (BZAW 101; Berlin, Töpelmann, 1966), 173-96; O. Kaiser, 'Der Sinnkrise bei Kohelet' in Der Mensch unter dem Schicksal (BZAW 161; Berlin: de Gruyter, 1985) 91-109; Preuß, Einfiilhrung in die alttestamentliche Weisheitsliteratur (Stuttgart: Kohlhammer, 1987) 175-76, 191; Goldingay, Theological Diversity, 22-23; Crenshaw, 'The Human Dilemma and Literature of Dissent' in D.A. Knight (ed.), Tradition and Theology in the Old Testament (Philadelphia: Fortress, 1977) 249-54; F.A. Spina, 'Qoheleth and the Reformation of Wisdom' in H.B. Huffmon (ed.), The Quest for the Kingdom of God. Studies in Honor of George E. Mendenhall (Winona Lake: Eisenbrauns, 1983) 267-70; Murphy, 'Recent Research on Proverbs and Qoheleth', Currents in Research 1 (1993) 120.

16Goldingay, Theological Diversity, 208. 
that Proverbs' key does not fit or have scholars been tampering with the lock?

\section{The Claim of 'Substantial Diversity' in Wisdom Theology 17} What gave rise to this view of a crisis in Israelite wisdom? There were three major factors: First of all, as historical-critical approaches gained wide-spread acceptance, traditional views regarding Solomonic authorship and the historical reliability of the narrative accounts of Solomonic wisdom (1 Ki. 3-4 and 10; 2 Ch. 1 and 9) were questioned. ${ }^{18}$ Differences between Proverbs and Ecclesiastes no longer were explained in terms of Solomonic biography, a procedure that commenced with the rabbis and early church fathers, ${ }^{19}$ but in terms of the development of religious thought in the course of Israel's history. With the abandonment of dogmatic defences of internal consistency as a necessary correlate of divine inspiration, contradictory perspectives no longer presented a problem. Apparent diversity within individual books, such as in Ecclesiastes and Job, were resolved not by positing an inner dialogue but rather by suggesting literary-critical disarray or identifying later redactional additions, which, when removed, further intensified the critical voice.

Secondly, on the basis of Ancient Near Eastern analogies, in which the emergence of pessimistic literature could be dated, for example, in Egyptian culture to the First Intermediate Period (including the 'Admonitions of Ipuwer' and the 'Dispute of a Man with his Ba'), it was assumed that the

\footnotetext{
${ }^{17}$ The term 'substantial' [contradiction] (i.e., true divergence in viewpoint) is used by Goldingay in Theological Diversity, 22-23, to describe the relationship between Job-Ecclesiastes and Proverbs, distinguishing this type of diversity from 'formal' (i.e., at the level of words), 'contextual' (i.e., reflecting the variety in circumstances which different statements address), and 'fundamental' (i.e., a matter of substance, indicating a basic disharmony at the level of ethical stance or religious outlook), 15-25.

${ }^{18}$ See the summary of the critical consensus by G.T. Sheppard, The Future of the Bible. Beyond Liberalism and Literalism (Canada: United Church Publishing House, 1990) 109-12.

${ }^{19}$ See especially S. Holm-Nielsen, 'The Book of Ecclesiastes and the Interpretation of it in Jewish and Christian Theology', ASTI $10(1975 / 76)$ 38-96.
} 
same shift occurred in Israel as a result of a major historical crisis or disjuncture, for which only the Babylonian exile qualified. Then one sought, in turn, to explain why the destruction of Jerusalem produced this type of theological response. For example, Harvey, in summarising Schmid's 1965 dissertation, Wesen und Geschichte der Weisheit, speaks of an historically occasioned 'wisdom crisis' in Egypt around 1200 $\mathrm{BC}$, though acknowledging that the 'crisis' in Babylonian wisdom was more the result of a theological than an historical development (traditional wisdom becoming dogmatic), and then concludes that 'the wisdom crisis represented by Ecclesiastes and Job is parallel to that of the other sapiential milieus, Egypt and Mesopotamia.'20

Thirdly, on the basis of their study of 'quotations' in Old Testament wisdom literature, some scholars have claimed, for example, that Job's comforters blindly quote traditional wisdom (i.e., Proverbs) while Qoheleth quotes it only in order to refute it.21 Thus it is concluded that the theology of traditional wisdom has been declared bankrupt by a later generation in Israel.

What are the consequences of positing this type of diversity in the Old Testament which might be viewed, using Goldingay's labels, as entailing 'substantial' or even 'fundamental' contradiction?22 In terms of theological evaluation, one is encouraged to choose between the two basic wisdom theologies: since the approach which is represented by Ecclesiastes and Job is later and more realistic, the choice

${ }^{20} \mathrm{~J}$. Harvey, 'Wisdom Literature and Biblical Theology (Part One)', BTB 1 (1971) 313, 318; see also Preuß, Einfiihrung, 22, 69.

${ }^{21}$ Important studies of quotation in wisdom literature include R. Gordis, 'Quotations in Wisdom Literature', JQR n.s. 30 (1939-40) 123-47; idem, Koheleth, the Man and his World. A Study of Ecclesiastes (3rd ed.; New York: Schocken Books, 1973); idem, The Book of God and Man. A Study of Job (Chicago: Univ. of Chicago Press, 1965); R.N. Whybray, 'The Identification and Use of Quotations in Ecclesiastes' in J.A. Emerton (ed.), Congress Volume: Vienna 1980 (VTS 32; Leiden: Brill, 1981) 435-51; M.V. Fox, 'The Identification of Quotations in Biblical Literature', ZAW 92 (1980) 416-31; D. Michel, Untersuchungen zur Eigenart des Buches Qohelet (BZAW 183; Berlin: de Gruyter, 1989).

22See note 17 above. 
should not be difficult to make. Hermeneutically, however, this drives a wedge through the middle of the Old Testament wisdom corpus, whose inherent authority is questioned, since it is viewed as deriving entirely from human observation and experience. The practical value of proverbial wisdom is diminished; the sentiments of Job and Ecclesiastes seem much more relevant to a cynical post-modern generation.

\section{The Case for Unity in Wisdom Theology}

Can a case be made for a basic unity in wisdom theology, despite clear evidence of formal and contextual diversity? In this section of the essay, after briefly considering several editorial or 'canonical' indicators of unity, we will examine the foundational theological convictions which all three wisdom books share. This warrants the conclusion that there is a fundamental theological unity within the wisdom corpus and suggests that Job's and Qoheleth's voice of protest should not be viewed as a rejection of traditional wisdom thought.

\section{(1) The Canonical Witness to the Unity of the Wisdom Corpus}

In the light of the canonical ascription of both Proverbs and Ecclesiastes to Solomon (Pr. 1:1; 10:1; 25:1; Ec. 1:1, 12), one justifiably may ask: how much dissonance or contradictory sentiment can be tolerated between two texts attributed to the same author? Could the wisest of all men, divinely endowed with measureless understanding ( $c f .1 \mathrm{Ki} .4: 29-34$ [5:9-14]) be viewed as later in life recanting or refuting his earlier proverbial writings? Though midrashic sources claim that Ecclesiastes was composed during or after a time of apostasy, the text itself suggests rather a systematic, almost scientific, investigation of all that is done under the sun (cf. 2:1, 3, 9).23

Meade suggests that the pseudonymous ascription of Ecclesiastes lent it authority by placing it 'firmly in the context of the Solomonic wisdom tradition', while Childs points out that 'as the source of Israel's wisdom, [Solomon's] words serve as an official corrective from within the wisdom tradition

${ }^{23}$ The best study of Qoheleth's 'epistemology' is by M.V. Fox, Qoltelet and his Contradictions (Sheffield: Almond, 1989) ch. 3. 
itself.'24 In other words, whoever was responsible for affixing (or retaining) the superscriptions to Proverbs and Ecclesiastes apparently did not consider the content of the latter to be inconsistent with Solomonic authorship.

\section{(2) The Significance of the Conclusion to Ecclesiastes}

Indeed, Sheppard and Wilson have argued that the so-called appendices to Ecclesiastes (12:9-14) serve a two-fold canonical function. First of all, far from refuting the contents of the rest of the book (as Fox and Longman have claimed ${ }^{25}$ ), these verses 'thematize' the book, making explicit the 'canonical definition' of sacred wisdom as embracing Torah obedience. ${ }^{26}$ More importantly, by referring to 'many proverbs' (משלים) and the 'words of the wise', terms also occurring in Proverbs 1:6, as being 'given by one shepherd' (vv. 9, 11), and warning against any additional writings (v. 12), the author of these verses asserts that Ecclesiastes and Proverbs together form an authoritative but exclusive wisdom corpus. ${ }^{27}$ Is it possible that Old Testament scholars have torn asunder too readily what a canonical editor joined together?

\section{(3) The Conformity of Job to Old Testament Piety}

Furthermore, a full-fledged attack on traditional wisdom also seems out of character for Job, whose description in the prologue and epilogue ('my servant Job', 'blameless and upright, fearing God and shunning evil', 1:1, 8; 2:3) and

${ }^{24}$ D.G. Meade, Pseudonymity and Canon: An Investigation into the Relationship of Authorship and Authority in Jewish and Earliest Christian Tradition (Grand Rapids: Eerdmans, 1986) 58; Childs, Introduction to the Old Testament as Scripture (Philadelphia: Fortress, 1979) 584. If one agrees with Childs it still must be determined precisely what kind of corrective Qoheleth intended.

${ }^{25}$ M.V. Fox, 'Frame-Narrative and Composition in the Book of Ecclesiastes', HUCA 48 (1968) 83-106; T. Longman III, 'Comparative Methods in Old Testament Studies: Ecclesiastes Reconsidered', TSF Bulletin 7 (1984) 5-9; R.B. Dillard and Longman, An Introduction to the Old Testament (Grand Rapids: Zondervan, 1994) 247-55.

${ }^{26}$ G.T. Sheppard, 'The Epilogue to Qoheleth as Theological Commentary', CBQ 39 (1977) 188.

27G.H. Wilson, "The Words of the Wise": The Intent and Significance of Qoheleth 12:9-14', JBL 103 (1984) 176-77. 
intercessory role (42:8-9) reminds one of Abraham and Moses or Noah, respectively. Would one who previously and ultimately was well served by the 'retribution dogma' become its leading 'canonical' critic? In sum, both the Old Testament descriptions of Solomon and Job and the superscriptions and appendices of the books associated with them suggest a basic harmony among the Old Testament wisdom books.

\section{Wisdom and the Retribution Dogma: Aspects of Agreement} If this is the case, then one must re-examine the nature and extent of the perceived tension within the wisdom corpus. Is there genuinely an irreconcilable conflict between JobEcclesiastes and Proverbs or is there another way to account for the diversity? It is our conclusion that a close examination of the structure and contents of these three books reveals far more unity than often is assumed with respect to the 'retribution dogma', usually considered to be the basic teaching of the proverbial collections. According to the popular presentation of this dogma, wise and righteous behaviour guarantees prosperity and success, while foolish and wicked behaviour inevitably leads to judgment and ruin. ${ }^{28}$

\section{(1) The Limitations of Wisdom}

First of all, all three books agree upon the limitations of wisdom in guaranteeing success. The book of Proverbs repeatedly warns against the assumption that one truly can 'master life' through wisdom, though that is precisely how the purpose of wisdom has been described by von Rad:29 'Do you see a man wise in his own eyes? There is more hope for a fool than for him.' (26:12, also vv. 5, 16; cf. 3:5, 7; 28:11, 26); 'Do not boast about tomorrow, for you do not know what a day may bring forth' (27:1). Proverbs 1:5 indicates that wisdom is never

${ }^{28}$ This dogma is succinctly expressed in D.K. Berry, An Introduction to Wisdom and Poetry of the Old Testament (Nashville: Broadman \& Holman, 1995) 21: 'In Proverbs the theology of retribution offers a pat answer to almost all questions of human fortunes. The wicked suffer; the righteous prosper.'

${ }^{29}$ von Rad, Wisdom in Israel, 74. However, von Rad also devoted a chapter (ch. 6) to the discussion of the 'Limits of Wisdom'. 
complete; one always can enhance, broaden, or deepen one's wisdom; consequently, incomplete wisdom cannot be completely effective in accomplishing its goal. Furthermore, wisdom cannot guarantee one a hearing: even Lady Wisdom's counsel and correction may fall on deaf ears (1:29-30).

Ecclesiastes acknowledges that wisdom and knowledge do not necessarily guarantee success ('The race is not to the swift or the battle to the strong, nor does food come to the wise or wealth to the brilliant or favour to the learned; but time and chance happen to them all,' 9:11) and can, instead, bring sorrow and grief (1:18). Wisdom can be despised and ignored (9:15-16). Wisdom may assist one in understanding the present but cannot discern the future $(3: 22 ; 6: 12 ; 7: 14 ; 8: 7 ; 9: 1,12 ; 10: 14 ; c f$. Pr. 27:1); the depth of wisdom necessary to solve all of life's conundrums is beyond human reach (7:23-24). To pretend to be wise (חכם hithpa'el) will lead only to a rude awakening (7:16).

Job focuses on wisdom not as a means for mastering life but rather as a means for explaining life's experiences. Job himself is not characterized as particularly wise (he is neither a Joseph nor a Daniel) but as morally upright and blameless. Job sarcastically impugns his comforters' wisdom as unable to explain his situation (12:1; cf. 26:3), a conclusion with which Elihu concurs (32:13). God's ways are beyond human comprehension (36:26, 29; 37:15-16; 38:18, 20-21, 36-37), and Job ultimately must confess that he spoke without understanding (42:1-3).

To sum up, the three wisdom books agree that wisdom neither guarantees success nor enables one to understand all matters. To claim to understand more than one does is the trademark of the fool!

\section{(2) Divine Freedom and Inscrutability}

Secondly, all three books affirm divine sovereignty and inscrutability as primary factors facilitating or hindering human success, acknowledging that God himself is the bestower of wisdom (Pr. 2:6; Ec. 2:26; Jb. 28:23). Furthermore, according to Proverbs, it is not human skill but rather 'the blessing of the LORD [which] brings wealth' (Pr. 10:22). People can search out matters through their wisdom, but God can 
conceal them (25:2). God's sovereignty does not negate human planning and actions but clearly can overrule these: 'The king's heart is in the hand of the LORD; he directs it like a watercourse wherever he pleases' $(21: 1 ;$ cf. 19:21; 20:24; 21:31); 'The LORD works out everything for his own ends-even the wicked for a day of disaster' (16:4, cf. 16:1, 3, 9, 33).

Ecclesiastes affirms that God can grant or withhold the ability to enjoy life's good things $(2: 25-26 ; 5: 19 ; 6: 2)$. What he has made crooked, no one can straighten. He makes both the pleasant as well as the unpleasant days (7:13-14) and determines the exact length of one's life (8:15). Ecclesiastes 9:1 sums it up well: 'So I reflected on all this and concluded that the righteous and the wise and what they do are in God's hands...'

Even to a greater extent than the other two wisdom books, Job repeatedly affirms God's absolute sovereignty and freedom: to allow but limit the afflicting of Job, to conceal his reasons for dealing in this manner with his servant (the reader knows more than Job ever learns), to speak to him from the whirlwind, and, ultimately, to restore Job's health and increase his prosperity. Job expresses it best: 'But he stands alone, and who can oppose him? He does whatever he pleases' (23:13).

To sum up, all three books affirm God's absolute sovereignty and humanity's utter dependence on him. Although the specific perspective of each book differs, due to the particular aspects of human experience which are being emphasized, there is no inherent warrant for viewing one book's portrayal of God as more negative than that of the others.

\section{(3) The Relative Value of Wisdom and Righteousness}

Thirdly, because of their similar understanding of God, all three books agree on the relative value of wisdom and righteousness. Proverbs understands that the world of the wise and the righteous also is populated by fools, the wicked, the lazy, the gossips, the adulteresses, and the perverse. In such a world, it is essential to embrace Lady Wisdom, for 'discretion will protect you, and understanding will guard you' (2:11), keeping you on 'the path of the righteous' (2:20). 
Although Proverbs 10-15, in particular, presents the benefits of being wise and righteous, especially in contrast to the consequences of being foolish and wicked, recent wisdom research indicates that the seemingly glowing promises in this section cannot be taken at face value. Several scholars have identified various ordering principles within the individual collections resulting in proverbial pairs, combinations, and groups. 30 This would indicate that the individual proverbs, regardless of the original Sitz im Leben which gave rise to them, have been ordered and re-contextualised so that their present 'Sitz im Text' now determines their meaning. Analysing proverbs within their literary context serves to relativise and qualify their promissory aspect, after the manner of the 'zwar...aber' (to be sure...however) pattern which Zimmerli identified in Ecclesiastes: ${ }^{31}$ Proverbs 10:3 claims that 'the LORD does not let the righteous go hungry but he thwarts the craving of the wicked' but then clarifies what this may involve in 10:4-5: 'Lazy hands make a man poor, but diligent hands bring wealth. He who gathers crops in summer is a wise son, but he who sleeps during harvest is a disgraceful son.' Similarly, 10:24 claims that 'what the wicked dreads will overtake him; what the righteous desire will be granted', but 10:25 clarifies that 'when the storm has swept by, the wicked are gone, but the righteous stand firm forever', implying that the righteous also must first weather the same storm that destroys the wicked.

${ }^{30}$ On ordering principles, see especially R.C. van Leeuwen, Context and Meaning in Proverbs 25-27 (Atlanta: Scholars Press, 1988); Whybray, 'Thoughts on the Composition of Proverbs 10-29' in E. Ulrich, et al., (eds.), Priests, Prophets and Scribes: Essays on the Formation and Heritage of Second Temple Judaism in Honour of Joseph Blenkinsopp (JSOTS 149; Sheffield: JSOT Press, 1992) 102-14; J. Goldingay, 'The Arrangement of Sayings in Proverbs 10-15', JSOT 61 (1994) 75-83; R. Scoralick, Einzelspruch und Sammlung: Komposition im Buch der Sprichwörter Kapitel 10-15 (BZAW 232; Berlin: de Gruyter, 1995).

${ }^{31} \mathrm{~W}$. Zimmerli, 'Prediger' in H. Ringgren and Zimmerli, Sprüche/Prediger (Göttingen: Vandenhoeck \& Ruprecht, 1962) 126-27. Properly understood, however, proverbial wisdom is neither absolute nor axiomatic, since, as T.A. Hildebrandt has suggested, it presents merely 'one aspect of reality' ('Proverbs' in D.B. Sandy and R.L. Giese, Jr. [eds.], Cracking Old Testament Codes. A Guide to Interpreting the Literary Genres of the Old Testament [Nashville: Broadman \& Holman, 1995] 248). 
Ecclesiastes clearly acknowledges the value of wisdom: 'I saw that wisdom is better than folly, just as light is better than darkness. The wise man has eyes in his head, while the fool walks in darkness' (2:13-14). However, both the fool and the wise will die and be forgotten (2:15-16). Though a righteous man can perish despite (or even because, Heb. ב) of his righteousness, while a wicked man lives long despite his wickedness (7:15, cf. 8:14), Qoheleth does not advocate either moral anarchy or a golden mean, as some interpreters understand 7:16-17,32 for he remains firm in his convictions that it ultimately will not go well for the wicked because they do not fear God (8:12-13).

In Job, wisdom is a highly valued commodity (ch. 28, especially v. 18), yet it does not enable Job or his friends to assess his situation correctly. Job defends his moral uprightness (ch. 31), as he clings to his 'integrity' (תמה: 2:9; 6:29-30; 27:3-6), yet he is suffering in a manner which no righteous individual deserves or expects ( $c f .27: 2$ ).

In sum, all three books agree that wisdom and righteousness are valuable but concede that these not only are imperfectly attainable by humans but are also unable to guarantee success or protection from the difficulties of life.

\section{(4) The Retribution Dogma}

Finally, the three wisdom books assume a similar stance regarding the relationship between deeds and consequences. Foundational to the theory of a 'crisis in Israelite wisdom' is the so-called retribution dogma. In its wisdom application, it was derived, on the one hand, from Koch's view of a 'consequenceproducing deed',33 and, on the other, from early Egyptian conceptions of a deterministic Ma'at-order. However, Brunner demonstrated that the close relationship between ethical conduct and reward or retribution which was evident in early

\footnotetext{
32See the discussion in Fox, Qohelet, 233-34. However, Ec. 7:20 suggests that, for humans, absolute righteousness is unattainable.

${ }^{33} \mathrm{~K}$. Koch, 'Gibt es ein Vergeltungsdogma im Alten Testament?', ZThK 52 (1955) 1-42. The great influence of Koch's essay is evidenced by the fact that Koch later edited an entire volume of essays on the subject: Um das Prinzip der Vergeltung in Religion und Recht (Darmstadt: WBG, 1972).
} 
texts no longer was conceived of as automatic by the Ramesside age, ${ }^{34}$ long before the rise of the Israelite monarchy, for it could be overruled by the divine will. Similarly, Koch's idea of an automatic or mechanical justice by which God himself was bound, merely presiding over the consequence to which the deed gave birth like a watchful midwife, has been subject to frequent criticism.

With respect to the book of Proverbs, Janowski demonstrates that retribution is more complex than Koch suggested, listing numerous verses from Proverbs in support: it can be either 'immanent' (i.e., automatic) or take place through social interaction or through the direct intervention of God, the latter two being dependent on someone taking the appropriate action. ${ }^{35}$ A more fundamental attack on Koch has been mounted by Hausmann and van Leeuwen. ${ }^{36}$ Hausmann claims that no clear-cut deed-consequence relationship is to be found in the early proverbial collections, citing proverbs like 11:21, $22: 8,24: 16$, and 30:17 which suggest that time is a crucial factor in understanding Proverbs' answer to the problem of injustice: one simply has to wait for justice to arrive. ${ }^{37}$ Similarly, van Leeuwen views the retribution doctrine as being relativised by Proverbs' 'contradictory juxtaposition of faith-and-wealth [proverbs]... with faith-and-poverty [proverbs]', for example in 3:9-12.38 These recent studies suggest that, if a rigid retribution dogma was derived from the older proverbial collections, it must have been based on their misuse or misinterpretation. 39

\footnotetext{
${ }^{34}$ Brunner's 'Der freie Wille Gottes in der ägyptischen Weisheit' was delivered at the Colloque de Strasbourg 17-19 May 1962 and reprinted in Brunner, Das hörende Herz. Kleine Schriften zur Religions- und Geistesgeschichte Ägyptens (OBO 80; Fribourg: Editions Universitaires, 1988) 85-102.

35B. Janowski, 'Die Tat kehrt zum Täter zurück. Offene Fragen im Umkreis des "Tun-Ergehen-Zusammenhangs"', ZThK 91 (1994) 247-41; cf. also Murphy, 'Wisdom Literature and Biblical Theology', 4.

36J. Hausmann, Studien zum Menschenbild der älteren Weisheit (Spr 10ff) (FAT 7; Tübingen: Mohr; 1995); R. van Leeuwen, 'Wealth and Poverty: System and Contradiction in Proverbs', Hebrew Studies 33 (1992) 25-36.

37Hausmann, Studien zum Menschenbild, 234.

${ }^{38}$ van Leeuwen, 'Wealth and Poverty', 34-35.

${ }^{39}$ Hausmann, Studien zum Menschenbild, 374.
} 
Similarly, Qoheleth does not question the existence of divine justice but is troubled rather by its timing:

And I saw something else under the sun: In the place of judgment-wickedness was there... I thought in my heart, 'God will bring to judgment both the righteous and the wicked for there will be a time for every activity, a time for every deed' (3:16-17, cf. 8:6-8).

Observed exceptions to justice, introduced by $\boldsymbol{\omega}$ (e.g., 7:15), do not weaken his convictions that justice ultimately will be carried out $(8: 12-13 ; 11: 9 ; 12: 13-14)$. Indeed, it is Qoheleth's conviction that God is good and just, though his ways are inscrutable, that enables him to find meaning and joy in this often brutal and disappointing world (2:24-26; 5:18-20).

With respect to the book of Job, Mettinger describes the God of Job's friends as the 'Lord of retribution'. 40 They clearly uphold the justice of God, even at the expense of Job's innocence. Job, too, however, is convinced of God's justice; that is why he demands a heavenly attorney to present his case before the divine tribunal. In the shortened third cycle, Job disarms his friends by turning their portrait of the wicked man into a mirror in ch. 27, maintaining his innocence, and labelling his 'friends' 'my enemies', thus qualifying them for the fate of the wicked. It is precisely because Job is so deeply convinced of God's justice that his unexplained suffering (but $c f .3: 25$ ) and his friends' merciless accusations evoke such a response from him. But Job's story illustrates the same principle regarding divine retribution as do Proverbs and Ecclesiastes: God is just but one might have to wait to experience justice. When Job's situation finally is reversed, it is not a folk tale's trivialising 'happy end', a reward for his patience, for, as Seitz points out:

one gains such a restoration from God by walking down no predictable path but down one that leads to the source of all

${ }^{40}$ T.N.D. Mettinger, In Search of God. The Meaning and Message of the Everlasting Names (Philadelphia: Fortress, 1988) 178. 
life and wisdom, even at moments of gravest danger and utter doubt about whether God is for us or against us. ${ }^{41}$

In sum, all three wisdom books contain the same highly nuanced doctrine of divine justice. There is no God-binding mechanistic principle, as Koch claimed, but the simple fact that, as Koorevaar summarises it, 'deeds have consequences.' 42 The wisdom theology of divine retribution is not dissimilar to that which is illustrated repeatedly in Israel's historical narratives: divine justice, in deliverance and punishment, often delayed and tempered by grace. However, though one even might describe the wisdom doctrine of retribution as overtly 'Deuteronomic',43 it qualifies the 'blessings and curses' theology sociologically in relating it primarily to individual members of the covenant nation rather than to the nation as a whole and serves as a theological counterbalance to a rigid application of the 'retribution principle', which suggests that God is susceptible to manipulation, by repeatedly affirming divine freedom.

Although there clearly are genuine differences between the books of Proverbs, Ecclesiastes, and Job in their particular emphases on the prospects and problems of success and suffering, we have sought to demonstrate that there is no textbased warrant for positing the sort of 'crisis in Israelite wisdom' that would demand a lengthy historical development or a jolting political or economic reversal to account for it. As in Mesopotamia and Egypt, proverbial and instructional wisdom could be promulgated at the same time as pessimistic and disputational wisdom.

Therefore, though Proverbs and Job-Ecclesiastes represent distinct generic options for communicating wisdom, it is misleading to characterize these books as containing contradictory wisdom theologies. Though wisdom by no means

${ }^{41}$ C.R. Seitz, 'Job: Full-Structure, Movement, and Interpretation', Interpretation 43 (1989) 17.

${ }^{42}$ H. Koorevaar, "Das Vergeltungsdogma" im Buch der Sprüche', Fundamentum 3 (1987) 48.

${ }^{43}$ This was suggested already by O.S. Rankin, Israel's Wisdom Literature. Its Bearing on Theology and the History of Religion (Edinburgh: T. \& T. Clark, 1936) esp. ch. 3. 
presents a monolithic ideology, Proverbs is in basic agreement with Job and Ecclesiastes that justice is not always immediately served, that wisdom will not give us mastery over life, and that God is not bound to reward or punish, to shelter or afflict, in response to human actions, expectations, or demands. Furthermore, Ecclesiastes and Job are in basic agreement with Proverbs that righteousness and wisdom are beneficial and that God does reward good and punish evil.44

\section{The Theological Moorings of Wisdom Theology: a Covenantal Perspective}

In the final section of this essay, we would like to consider the provenance of wisdom theology. If the case which was made in the preceding section for the fundamental unity of wisdom theology can be sustained, then it is appropriate to ask whether one explanation for this unity lies in the wisdom corpus' common theological roots in Israel's covenant faith.

\section{Digging for Wisdom's Roots: Preliminary Issues}

Before we examine the various theological strands which link the wisdom books with the rest of the Old Testament, there are several issues which must be addressed briefly.

First of all, some would consider it unnecessary, even harmful, to attempt to incorporate wisdom theology into the mainstream of Old Testament theology. We previously noted Goldingay's reminder that diversity can be enriching. Perhaps one should be content to include wisdom within some type of dialectical or polar relationship with another major theological emphasis of the Old Testament (e.g., God's acts and Israel's response [Zimmerli, Childs]; national salvation and creation blessing [Westermann, Goldingay]; or perhaps nationalism and universalism or special and natural revelation). Seeking to

\footnotetext{
${ }^{44}$ One must acknowledge, of course, that many commentators offer a more negative assessment of the message of Ecclesiastes. However, Whybray has demonstrated that a positive interpretation also can do justice to the text, cf. 'Qoheleth, Preacher of Joy', JSOT 23 (1982) 87-98 and Ecclesiastes (London: Marshall, Morgan \& Scott, 1989); also M. Klopfenstein, 'Kohelet und die Freude am Dasein', TZ 47 (1991) 97-107.
} 
assign Old Testament wisdom to the theological mainstream could lead to downplaying or ignoring its unique theological contribution, e.g., to the Old Testament themes of cosmology and anthropology. 45

Furthermore, the problem of integration may not be posed by the wisdom literature itself but rather by too narrow a conception of Old Testament theology. As Murphy and others have complained, 46 by making revelation in history determinative for Old Testament theology, scholars have excluded wisdom literature by definition. Smith's recent proposal to construct an Old Testament theology on the basis of the Old Testament portrayal of God's sovereign rule over individuals, nations, and nature certainly would accommodate wisdom literature quite comfortably. 47

The goal of this section, however, is not to propose a new, more adequate, centre for Old Testament theology or even to distil the essence of wisdom theology but, more modestly, to identify the theological roots of wisdom literature and thereby demonstrate that its teachings are an integral and genuine expression of Israelite faith, despite its unique subjects and emphases.

Secondly, some might suggest that we are looking in the wrong place for wisdom's theological roots: one must not look within to Israel's canonical writings but around to Israel's wise neighbours from whom it borrowed amply and continuously. The Old Testament not only acknowledges Israel's acquaintance with foreign wisdom but apparently incorporates it within its own wisdom corpus (e.g., the sayings of Agur and Lemuel's mother). However, Weeks recently has exposed a number of flawed assumptions and erroneous conclusions, which too long have passed for 'assured results': that borrowing always was a one-way street, that Israel adopted rather than adapted foreign wisdom motifs, that verbal similarities imply conceptual similarities, that the development

45So Perdue, Wisdom \& Creation, 341.

${ }^{46}$ Murphy, 'The Interpretation of Old Testament Wisdom Literature', Interpretation 23 (1969) 292.

${ }^{47}$ G.V. Smith, 'Is There a Place for Job's Wisdom in Old Testament Theology?', TJ 13 (1992) 16. 
of wisdom in other cultures must have had similar causes and effects or purposes and applications within Israel. 48

A judicious application of a contrastive-contextual approach ${ }^{49}$ could result in a different assessment of Old Testament wisdom literature: Ancient Near Eastern wisdom literature is so diverse that its implications for the absolute dating of Old Testament wisdom texts are inconclusive, for some features which are early in Mesopotamia are late in Egypt and some later Egyptian texts are simpler and less theological than earlier ones. The existence of similar genres, concepts, themes, and expressions in the third and second millennium BC make a pre-exilic dating of the Old Testament wisdom books possible, perhaps even likely. For example, since Egyptian wisdom had become 'theological' and a mechanical view of Ma'at-order had been abandoned before the emergence of Israel as a nation, the view that a purely secular wisdom or a rigid act-consequence dogma was dominant in Israel until after the exile is unlikely. 50

Thirdly, some would consider it hazardous to compare wisdom writings with other Old Testament literature when the integrity and relative dating of various books or redactional reworkings thereof are still much disputed. However, it is still legitimate and useful to examine the intertextual relationships of wisdom literature even though the issue of literary chronology has not been resolved. The Torah clearly holds a

48S. Weeks, Early Israelite Wisdom; cf. also K.A. Kitchen, 'Biblical Instructional Wisdom: the Decisive Voice of the Ancient Near East' in a forthcoming Festschrift for Cyrus Gordon.

${ }^{49}$ This use of ANE materials is particularly associated with the work of W.W. Hallo, $c f$. his recent essay 'Compare and Contrast: The Contextual Approach to Biblical Literature' in Hallo, et al. (eds.), The Bible in the Light of Cuneiform Literature. Scripture in Context III, (Lewiston: Mellen, 1990) 130.

50See Weeks for a general discussion; also B. Gemser, 'The Instructions of 'Onchsheshonqy and Biblical Wisdom Literature', VTS 7 (Leiden: Brill, 1960) 102-28, and D. Römheld, Wege der Weisheit. Die Lehren Amenemopes und Proverbien 22,17-24,22 (BZAW 184, Berlin: De Gruyter, 1989) regarding theological development within Egyptian wisdom literature. However, it is questionable whether Israelite culture ever developed along parallel lines with Egyptian or Mesopotamian cultures, given the unique impact of Baalism upon Israel. 
foundational place within the Old Testament canon and one can relate various texts to the foundational narrative of Israel's history. 51

\section{Covenant Theology and Wisdom Literature}

There is one matter upon which nearly all recent publications on Old Testament wisdom are agreed: that it originally had little or nothing to do with the distinctives of Israel's covenant faith. 52 To be sure, Priest may be correct in suggesting that the sages seldom mentioned their covenantal convictions because they were presupposed, but, even if this were the case, the wisdom writings ought to reflect this in some respect. ${ }^{53}$ Our task, then, is to determine the extent to which the Old Testament wisdom literature shares the same theological concepts and perspectives as the rest of the Old Testament. 54

${ }^{51}$ See L.M. Eslinger, 'Inner-Biblical Exegesis and Inner-biblical Allusion: The Question of Category', VT 42 (1992) 47-58.

${ }^{52}$ Typical in this regard is William L. Holladay's monograph Long Ago God Spoke. How Christians May Hear the Old Testament Today (Minneapolis: Fortress, 1995) in which he discusses wisdom literature under the rubric 'beyond the covenant', 231. This is not to suggest that scholars have not noted the interconnectedness between the major divisions of the Old Testament canon. W. Brueggemann, The Creative Word. Canon as a Model for Biblical Education (Philadelphia: Fortress, 1982), for example, discusses the 'Torah-isation' of wisdom and the restudying of Torah 'in sapiential categories' (pp. 110, 112).

53J. Priest, 'Where is Wisdom to be Placed?', JBR 31 (1963) 275-82. According to von Rad, Wisdom in Israel, 64, it would have been 'inconceivable' for Israel's wisdom teachers that their knowledge of life could function 'independently of their faith in Yahweh'.

${ }^{54}$ Recent discussions of the theological provenance of Old Testament wisdom include: B.K. Waltke, 'The Book of Proverbs and Old Testament Theology', BibSac 136 (1979) 302-17; B.V. Malchow, 'Wisdom's Contribution to Dialogue', BTB 13 (1983) 111-15; Scobie, 'The Place of Wisdom in Biblical Theology' (1994), 43-48; A.W. Jenks, 'Theological Presuppositions of Israel's Wisdom Literature', HBTh 7 (1985) 43-75; L. Wilson, 'The Place of Wisdom in Old Testament Theology', RThR 49 (1990) 60-69; and Murphy, 'Wisdom Literature and Biblical Theology' (1994). 
(1) The God of the Sages and the God of the Old Testament Boström notes that more than ten percent of the proverbs refer to God, usually using the name Yahweh. ${ }^{55}$ However, this is no mere re-labelling of a pagan deity to fit Israelite requirements. Boström concludes his exhaustive study of God in Proverbs by stating that the portrayal of God in Proverbs, both as transcendent and sovereign creator and as personal protector, 'exhibits the most fundamental relationship to the wisdom traditions and other traditions of the Old Testament.'56 The dialogues of Job use Elohim or Shaddai, but the prologue and epilogue use Yahweh $(38: 1 ; 40: 1,3,6 ; 42: 1,7,9,10,11,12)$, as if consciously identifying the God who addresses Job with the God of Israel. Mettinger argues that there are three distinct portrayals of God in the book of Job: the God of the friends, the God of Job, and the God of the whirlwind. The first two, however, are proven to be errant by the third which, in its theophany and exaltation of God's sovereign power clearly parallels portrayals of God elsewhere in the Old Testament, including the supreme theophany on Sinai. 57 Qoheleth's view of God is more disputed. Michel claims that Qoheleth's God is 'not the God of Abraham, not the God of Isaac, not the God of Jacob, not the God in Jesus Christ', and Preuß suggests that Qoheleth's God, who is referred to exclusively as Elohim (forty times, occurring twenty-six times with the 'distancing' definite article) is best called 'the deity'. Whybray, however, disagrees:

This God, whom he calls (ha-)Elohim but who is in fact identical with the Yahweh of the Old Testament, is the sole creator of the world and holds the fate of every human being in his hands. 58

\section{(2) The Foundational Relationship - the Fear of the LORD}

If the God of the sages is essentially identical with the God of the rest of the Old Testament, then one could assume that

${ }^{55} \mathrm{~L}$. Boström, The God of the Sages. The Portrayal of God in the Book of Proverbs (Stockholm: Almqvist \& Wiksell, 1990) 33-34.

${ }^{56}$ Boström, ibid., 238.

57Mettinger, In Search of God, 186.

$58 \mathrm{Michel}$, Untersuchungen zur Eigenart des Buches Qohelet, 289; Preuß, Einfiillrung, 127-28; Whybray, Ecclesiastes, 27. 
humanity's relationship to him also should be portrayed similarly. The most important phrase which expresses this relationship is the 'fear of the LORD' or the 'fear of God', which Walter Kaiser has termed 'the key theme of wisdom literature', though its use cannot be linked in each instance to the covenant promises, as Kaiser appears to do. ${ }^{59}$ The phrase occurs eighteen times in Proverbs, five times in Ecclesiastes, and ten times in Job, along with several related expressions. More significant than the frequency is the location of the phrase: framing the theological introduction to Proverbs $(1: 7,29 ; 2: 5 ; 8: 13 ; 9: 10)$, concluding the portrayal of wisdom incarnate (31:30); characterising Job as morally impeccable $(1: 1,8,9 ; 2: 3)$, climaxing Job's hymn to wisdom (28:28), and closing the book of Ecclesiastes (12:13).

It is incorrect simplistically to equate 'the fear of the LORD' or 'the fear of God' in wisdom texts with its use outside of the wisdom corpus (e.g., Gn. 22:12; 42:18; Ex. 1:21; 14:31; 20:20; Lv. 19:14, 32; 25:17; Dt. 4:10; 5:29; 6:2, 13, 24; 8:6; 10:12, 20; Jos. 4:24; 24:14; 1 Sa. 12:14, 24; 2 Sa. 23:3; 1 Ki. 18:12; Ps. 2:11; $19: 9 ; 111: 10 ; 128: 1$; Is. 11:3; 33:6), for, as Becker has noted, the fear of God in the Old Testament can be numinous, cultic, ethical, or nomistic. 60 However, it at least can be affirmed that the wisdom books describe the relationship to God in the same manner as the rest of the Old Testament canon.

With respect to the use of the phrase in the individual books, Hausmann has noted that in Proverbs the 'fear of the LORD' exclusively relates to the vertical (God-man) rather than the horizontal (interpersonal) relationship, and Wilson has argued that in Job the fear of God is not rejected but merely qualified in terms of its adequacy 'to cover the whole field of human response'.61

\footnotetext{
${ }^{59}$ W.C. Kaiser, Jr., 'Wisdom Theology and the Centre of Old Testament Theology', EQ 50 (1978) 138; cf. Waltke's corrective comment, 'The Book of Proverbs and Old Testament Theology', 303.

${ }^{60} \mathrm{~J}$. Becker, Gottesfurcht im Alten Testament (Rome: Pontifical Biblical Institute, 1965).

61J. Hausmann, Studien zum Menschenbild, 273; L. Wilson, 'The Book of Job and the Fear of God', TB 46 (1995) 76.
} 
More disputed is the use of 'fear of God' in Ecclesiastes, which Lauha distinguishes from that in Proverbs, characterising the former as shuddering 'respect for an incomprehensible despot'. However, this is hardly necessary in 7:18 where the fear of God leads to the avoidance of pretentious righteousness and excessive wickedness (vv. 16-17), or in 8:1213 where the God-fearer is contrasted with the wicked person who commits 'a hundred crimes' (NIV). Ecclesiastes 12:13, which directly links the fear of God to obeying the law, often is dismissed as a later addition, but Becker insists that this usage, whether stemming from the author or a redactor, is an appropriate expression of Qoheleth's 'intellectual world'.62 Indeed, Qoheleth uses the phrase similarly in 5:7[6] to warn against carelessness regarding cultic vows. This usage, however, has its closest parallels in Deuteronomy (especially $6: 2$; also $4: 10 ; 5: 29 ; 6: 13,24 ; 8: 6 ; 10: 12,20 ; 13: 4[5] ; 14: 23 ; 17: 19$; $25: 18 ; 31: 12-13)$. Thus, at least in some verses in Ecclesiastes, the phrase 'the fear of the LORD/God' may not only describe a common Israelite attitude toward God but also imply covenant obedience. Gese summarises:

In Israel wisdom of necessity consisted in the fear of Yahweh. Human attitudes can be explained in terms of this fear in the same categories as are appropriate in terms of Torah and of prophetic writings. Differences in nuance can be explained by the differences in form between the divine command and wisdom warnings, and by the corresponding differences in Sitz im Leben, but not by a discrepancy in content. 63

\section{(3) Covenant Standards and Covenant Obedience}

This raises the question of whether covenant standards and consequences are referred to explicitly in the Old Testament wisdom corpus. The relationship between wisdom and law has been the subject of much discussion, primarily focusing on a

62A. Lauha, Kohelet (Neukirchen-Vluyn: Neukirchener, 1978) 17, 70, similarly Preuß, Einfiihrung, 129; Becker, Gottesfurcht im Alten Testament, 254-55.

${ }^{63} \mathrm{H}$. Gese, 'The Law' in idem, Essays in Biblical Theology (Minneapolis: Augsburg, 1981) 77, emphasis by this writer. 
common Sitz im Leben for both within the family circle (the socalled Sippenethos), which has been posited on the basis of formal and conceptual parallels, ${ }^{64}$ or on Ben Sira's late equation of wisdom and Torah (24:23). 65 It was, in fact, common to link wisdom and law at the end of the previous century, viewing wisdom teaching as the practical application of ethical prescriptions as they are contained in the law as "objective" teaching to the "subjective" life of man.'66 What textual evidence is there of a close relationship between wisdom and law, regardless of the relative dating of the relevant literary sources?

(a) Individual Laws So striking are the parallels between Proverbs and Deuteronomy, that Weinfeld claimed that the latter drew from the former for its standards, while the former borrowed from its neighbours. These include the warning against dishonesty in commerce (Pr. 11:1; 16:11; 20:10, 23//Dt. 25:13-16, cf. Lv. 19:35-36, cf. also Pr. 6:30-31//Ex. 22:1) and moving boundary stones (Pr. 22:28; 23:10//Dt. 19:14; 27:17) and the commands to honour parents (Pr. 13:1; 15:5; 19:26; 20:20; 28:24//Dt. 5:16; 21:18, 21; 27:16) and avoid adultery (Pr. 22:14//Dt. 5:18; 22:22). Although these proverbial injunctions are not without parallels in Egyptian wisdom (compare, for example, Amenemope ch. 6 regarding moving boundary stones and ch. 16 regarding falsifying scales), there is no inherent reason not to assume that the sage derived his ethical standards from the covenantal law, if this already had been formulated.

${ }^{64}$ See Whybray, 'The Social World of the Wisdom Writers' in R.E. Clements (ed.), The World of Ancient Israel. Sociological, Anthropological and Political Perspectives (Cambridge: CUP, 1989) 227-50. Wisdom and law as Sippenethos has been defended most notably by E. Gerstenberger, Wesen und Herkunft des 'apodiktischen Rechts' (WMANT 20; Neukirchen-Vluyn: Neukirchener, 1965) and W. Richter, Recht und Ethos. Versuch einer Ortung des zveisheitlichen Mahnspruches (SANT 15; Munich: Kösel, 1966).

65But note already Dt. 4:5-6. E.J. Schnabel, Law and Wisdom from Ben Sira to Paul. A Tradition Historical Enquiry into the Relation of Law, Wisdom, and Ethics (WUNT 2/16; Tübingen: Mohr, 1985) ch. 1.

${ }^{66}$ As summarised by Schnabel, Law and Wisdom, 1-2. See, for example, H. Schultz, Alttestamentliche Theologie (Göttingen: Vandenhoeck \& Ruprecht, 1889) 478. 
(b) Cult-offerings and vows Proverbs encourages the bringing of first-fruits offering (Pr. 3:9-10//Dt. 26:1-11, also Ex. 23:16, 34:26; Lv. 2:14; Nu. 18:12) and refers to the fellowship and vow offerings (Pr. 7:14; Lv. 27:2-29; Nu. 30:3). Ecclesiastes not only speaks of the clean and the unclean and the sacrificers and non-sacrificers (9:2), possibly also referring to Temple worship (8:10: ממום קדוש, certainly not the cemetery!), but explicitly quotes from the deuteronomic law regulating oaths: (Ec. 5:4-6[3-5]//Dt. 23:21-23[22-24]). Job's confession of innocence, in disavowing the worship of the sun and moon (31:26-28), may not be distinctively Israelite, but certainly points to a monotheistic faith which was not widespread in the Ancient Near East.

Perdue demonstrated already in 1977 that wisdom literature also was interested in the cult. 67 More recently, Ernst, after a detailed examination of several proverbs containing 'cultic criticism' (15:8, 29; 17:1; 21:3,27; 28:9; also 14:9; 16:6), concludes that the proclamation of Amos, Isaiah, and Hosea presupposes this wisdom critique. 68

(c) Justice The call for justice in wisdom literature also parallels that in the law, including the warning against partiality in judgment (Pr. 17:15, 26; 18:5; 24:23-25/ /Dt. 1:16-17, 27:25; cf. Ex. 23:1-3), against giving and receiving bribes (Pr. 15:27; 17:8, 23; 19:6; 21:14//Dt. 10:17; 16:18-20; 27:25, cf. Ex. 23:8), and against perjury (Pr. 6:19; 12:17, 19; 14:5, 25; 19:5, 9, 28//Dt. 5:20; 19:15-21, 22:13-19; cf. Ex. 20:16; 23:1), and the admonition to care for the widow, the orphan, and the poor (Pr. $14: 20-21,31 ; 15: 25 ; 17: 5 ; 19: 17 ; 21: 13 ; 22: 7,9,16 ; 23: 10-11 / / D t$. 15:7-11; 24:11-12; 27:19).

(d) Covenant Vocabulary In the light of the common standards of wisdom and law, it is not surprising that obedience and disobedience also are described using similar terms in both literatures. Sin frequently is referred to as an

67L.G. Perdue, Wisdom and Cult. A Critical Analysis of the Viezus of Cult in the Wisdom Literatures of Israel and the Ancient Near East (SBLDS 30; Missoula: Scholars Press, 1977).

${ }^{68} \mathrm{~A}$. Ernst, Weisheitliche Kultkritik. Zu Theologie und Ethik des Sprïchebuches und der Propheten des 8. Jahrhunderts (BTS 23; Neukirchen-Vluyn: Neukirchener, 1994) 202. 
abomination (תועבה: Deuteronomy 17 times; Proverbs 21 times), authoritative instruction as torah (תורה: Deuteronomy 22 times; Proverbs 13 times) or commandments (מצות: Deuteronomy 42 times; Proverbs 8 times). Je. 18:18 suggests that the עצה (counsel) of the wise is on the same level as the תורה (word) of the prophet, at least in Jeremiah's day.69 As Gese expresses it: 'Wisdom, on the authority of Yahweh, called for persons to decide between life and death... using prophetic and deuteronomic vocabulary. ${ }^{\prime 70}$

In Proverbs 29:18 ('Where there is no revelation, the people cast off restraint; but blessed is he who keeps the law'), however, it is more likely that תורה refer to prophetic revelation and Mosaic law, respectively, rather than wisdom instruction. Because of its inherent authority, wisdom instruction is to be 'bound around the neck' and 'written on the heart' (Pr. 1:9; 3:3, 22; 6:21; 7:3//Dt. 6:8; 11:18), for wisdom is not simply an intellectual endeavour but also has an ethical dimension: doing what is 'right and just and fair' $(1: 3 ; 2: 9)$. Thus it is understandable that the categories wise/foolish, though not synonymous, are co-referential with righteous/ wicked: Proverbs 9:9; 10:21, 23; 23:24.71

\section{(4) Individualism, Israel's Covenant, and Divine Retribution}

How is one to understand the striking parallels between covenantal and wisdom ethics, in the light of the corporate/ national nature of the covenant and the individual/universal

${ }^{69}$ See B. Gemser, 'The Spiritual Structure of Biblical Aphoristic Wisdom. A Review of Recent Standpoints and Theories' in Adhuc Loquitur: Collected Essays of Dr. Berend Gemser (Leiden: Brill, 1968) 144-46, regarding the authority of wisdom counsel; also Waltke, 'The Book of Proverbs and Old Testament Theology', 308-10; and the discussion of Je. 18:18 in Brueggemann, The Creative Word, 7-9.

${ }^{70} \mathrm{Gese}$,'The Law', 77-78.

${ }^{71}$ So K. Heim, 'Coreferentiality, Structure and Context in Proverbs 10:1-5', JOTT 6 (1993) 183-209; earlier, W. Zimmerli, 'The Place and Limit of the Wisdom in the Framework of the Old Testament Theology', SJT 17 (1964) 152: 'Wise' can be replaced by 'righteous', 'fool' by 'wicked'; contra R.B.Y. Scott, 'Wise and Foolish, Righteous and Wicked', VTS 23 (Leiden: Brill, 1972) 146-65. Note also the frequent use of the terms righteous/wicked in Ecclesiastes and Job. 
nature of wisdom? Clements has suggested that, in the postexilic period, this feature helped the Diaspora Jews to maintain their faith without recourse to Temple and monarch. 72 However, one also could understand the wisdom teacher as claiming that (covenant) blessings are available to those who walk in the fear of the LORD, even if the nation as a whole is apostate. Conversely, since God may delay the ultimate punishment of a nation, wickedness may evoke divine wrath upon individuals 'before one's time' (Ec. 7:17; 8:8).

In any case, wisdom literature repeatedly uses language which is strikingly similar to that which is used in describing the covenantal blessings and curses (e.g., Dt. 28). Wise behaviour in the fear of the LORD leads to long life (Pr. 3:1-2, 33-35; 4:10-19; 8:32-36 //Dt. 5:16; 11:26-28; 30:15-18) and possession of the land (Pr. 2:20-22//Dt. 5:32-33; 30:15-18), while folly brings death and disobedience brings judgment. With regard to Proverbs 1-9, Waltke has noted that Lady Wisdom's scorn in 1:22-33 resembles the prophetic announcements of doom in tone, 73 and Michel identifies close parallels to Proverbs 2:21-22 ('For the upright will live in the land and blameless will remain in it, but the wicked will be cut off from the land, and the unfaithful will be torn from it') in Psalms 37:9, 11, 22, 28, 29, $34,38,39 ; 102: 28[29]$ and Isaiah $65: 8-9,11-12$; and suggests that Deuteronomy 28:63 is the source of the rare verb $\Pi 0$ I in 2:22.74 However, suffering, as in Job's case, may not always involve judgment: According to the sage, God as 'father' may deem it necessary to reprove his 'children' lest severer punishment be necessary (Pr. 3:11-12//Dt. 8:2-5).

\footnotetext{
72R.E. Clements, Wisdom in Theology (Grand Rapids: Eerdmans, 1992) 1339.

73Waltke, 'Lady Wisdom as Mediatrix. An Exposition of Proverbs 1:20-33', Presbyterion 14 (1988) 14-15, esp. 13.

${ }^{74}$ Michel, 'Proverbia 2-ein Dokument der Geschichte der Weisheit' in J. Hausmann and H.-J. Zobel (eds.), Alttestamentlicher Glaube und Biblische Theologie (Stuttgart: Kohlhammer, 1992) 235-38.
} 
(5) Other Canonical Links with Israel's History and Faith

In addition to the textual evidence already cited which suggests that wisdom literature is rooted deeply in Israel's covenant faith, there are many other intertextual connections between the wisdom corpus and the larger Old Testament canon.

It often has been claimed that wisdom literature is ahistorical. However, within the Old Testament canon, wisdom literature has been historicised. By virtue of the superscriptions which associate Proverbs, Ecclesiastes, and the Song of Songs with Solomon, whose reputation for unsurpassed wisdom is emphasized in 1 Kings and 2 Chronicles, Old Testament wisdom is grounded firmly in Israel's historical experience, the biblical narrative describing its divine source (1 Ki. 3:1-5), practical benefits $(3: 16-28 ; 5: 12)$, international context $(4: 29-31$, $34)$, literary expression (4:32-33), and potential ineffectiveness (i.e., limitations, 11:1-13). Thus it is not surprising to find similar themes emphasized in the wisdom corpus. These associations may lead the reader of these wisdom books to read them against the background of the prosperous circumstances of the Solomonic age. ${ }^{75}$

In the case of Ecclesiastes, the association of 'Qoheleth' with the Solomon of the historical narratives is particularly prominent. Both those scholars who still defend the Solomonic authorship of the book and those who attribute it to an anonymous or pseudonymous author agree that the correlation between the autobiographical details in Ecclesiastes and the biographical accounts in Kings and Chronicles indicates that it is Solomon's experiences and perspective that are being related in the book. This identification also is confirmed by other verbal parallels (e.g., Ec. 7:20: 'There is not a righteous man on earth who does what is right and never sins'//1 Ki. 8:46: 'When

${ }^{75}$ This differs greatly from the standard critical reading of the wisdom corpus. In Crenshaw's opinion (Old Testament Wisdom, 44, 48) 'an impregnable mountain called Fantasy stands between biblical interpreters and the historical Solomon...In short, Solomon's literary works either were non-existent or have disappeared.' With regard to the superscription in Pr. 25:1, see M. Carasik, 'Who were the "Men of Hezekiah"?', VT 44 (1994) 289-300, who sees here a proto-Midrashic interpretative activity similar to that possibly underlying some of the psalm superscriptions. 
they sin against you-for there is no one who does not $\sin ^{\prime}$ ). Even Qoheleth's familiar refrain 'eat, drink, and enjoy your work' can be understood not as a hedonistic carpe diem but rather as the fulfilment of the covenantal promise as national blessing: 'The people of Judah and Israel were as numerous as the sand on the seashore; they ate, they drank and they were happy' (1 Ki. 4:20).

Numerous verbal parallels between Proverbs and nonwisdom books also have been noted, not all of which are equally significant. ${ }^{76}$ However, in Proverbs 30:1-9 there apparently has been a conscious effort to compare and link proverbial wisdom with other canonical works. The location of this passage following the final proverbial collection (chs. 2529) and the use of the designation 'Holy One' only in 9:10 and 30:3 suggest that Proverbs 1-9 and 30-31 form a theological bracket around the individual collections. Proverbs 30:1-9 is filled with possible allusions to, and quotations of, other canonical books. Gunneweg suggests the following: v. 2// Psalm 73:22; v. 3//Psalm 73:17a; v. 4//Job 38f; v. 5//Psalm 18:30[31]; 12:6[7]; 19:8b-9[9b-10]; 119:140; v. 6//Deuteronomy $4: 2 ; 13: 1$. The most significant of these are the parallels in Psalm 18 (a psalm ascribed to David) and Deuteronomy 4, the sage apparently affirming that wisdom -writings also are the 'flawless word of God' to which, like the Mosaic Torah, 'nothing should be added'. This should be understood not as the claim by the proponent of an independent wisdom tradition that it is equally authoritative but rather as Agur's 'canon conscious' attempt to link proverbial wisdom to other 'divinely inspired' writings.77

76A. Robert listed almost countless verbal parallels between Proverbs and
other canonical books, especially Deuteronomy, Jeremiah, and 'Deutero-
Isaiah', 'Les attaches littéraires bibliques de Prov. i-ix', RB 43 (1934) 42-68,
172-204, 374-84; 44 (1935) 344-65, 502-25; cf. now also S.L. Harris, Proverbs
1-9. A Study in Inner-Biblical Interpretation (Atlanta: Scholars Press, 1997).
77These parallels already were noted by G. Sauer, Die Spriiche Agurs
(BWANT 84; Stuttgart: Kohlhammer, 1963) 101; and Childs, Introduction to
the Old Testament, 556-57, but recently they have received more detailed
examination by P. Franklyn, 'The Sayings of Agur in Proverbs 30: Piety or
Scepticism?', ZAW 95 (1983) 238-52; A.H.J. Gunneweg, 'Weisheit,
Prophetie und Kanonformel. Erwägungen zu Proverbia 30,1-9' in 
Like Proverbs and Ecclesiastes, the wisdom discourse of Job is not abstract or theoretical but is set within an historical framework, with a personal story, names, geographical location, and circumstances which could fit within the patriarchal period. The prophet Ezekiel, furthermore, affirms the 'historical' personage of Job in Ezekiel 14:12-23, mentioning him along with Noah and Daniel and possibly alluding to various details regarding Job from the prologue: righteous but, when stricken by four blows, able to save only himself.78

Though ostensibly an example of 'foreign wisdom', the book of Job obviously has been integrated into the Old Testament canon. After listing and discussing numerous 'affinities' (e.g., phrases and metaphors) between Job and other books, primarily Proverbs, Psalms, and Lamentations, and Isaiah, though few of the phrases which he cites are identical, Hartley concludes that the author's thought was saturated with his national literature. ${ }^{79}$

Scholars repeatedly have emphasized the great influence which wisdom literature or the wisdom tradition has had on the rest of the Old Testament canon. 80 Perhaps more attention should be devoted rather to assessing the possible influence which the rest of the Old Testament has had on the wisdom corpus or, at least, to appraising the extensive

Alttestamentlicher Glaube, 253-60; and R.D. Moore, 'A Home for the Alien: Worldly Wisdom and Covenantal Confession in Proverbs 30,1-9', ZAW 106 (1994) 96-107.

${ }^{78}$ See U. Berges, 'Der Ijobrahmen (Ijob 1,1-2,10; 42,7-17)', BZ 39 (1995) 22931.

${ }^{79}$ J.E. Hartley, Job (Grand Rapids: Eerdmans, 1988) 11-15; similarly Crenshaw, Old Testament Wisdom, 122; J.G. Janzen, Job (Atlanta: John Knox, 1985) 10-14; D. Wolters, Deep Things Out of Darkness. The Book of Job (Kampen: Kok, 1995) 91-94; but note J.J.M. Roberts' dissenting opinion, 'Job and the Israelite Religious Tradition', ZAW 89 (1977) 107-14.

${ }^{80}$ Despite Crenshaw's warning ('Method in Determining Wisdom Influence upon "Historical" Literature', JBL 88 [1969] 129-42) and Week's critique (Early Israelite Wisdom, chs. 5-6), the search for sapiential influence in the rest of the Old Testament has by no means been abandoned, as the Emerton Festschrift, Wisdom in Ancient Israel, illustrates, including chapters on wisdom and the Old Testament narrative traditions, Amos, Hosea, Isaiah, Jeremiah, Psalms, and Daniel. 
intertextual connections between the wisdom corpus and nonwisdom expressions of Israel's covenant faith and history.

\section{Wisdom and Creation Theology}

Although our primary concern in this section has been to build a case for locating one of Old Testament wisdom's theological roots in Israel's covenant faith, we cannot conclude our study of wisdom theology without briefly discussing another of its proposed theological roots: creation. Since Zimmerli's influential 1962 lecture on 'The Place and Limit of the Wisdom in the Framework of the Old Testament Theology', wisdom theology predominantly has been characterized as 'creation theology'. 81

What precisely is meant by creation theology? Those scholars emphasising this theme have noted three respects in which wisdom literature can be viewed as containing a 'creation theology': firstly, in its emphasis on God as Creator, secondly, in its emphasis on humanity in general (as opposed to Israel as the elect nation), and thirdly, in its emphasis on nature as divinely ordered. It is not our purpose here to defend or expound the creation theology of the Old Testament wisdom books but rather to determine whether creation actually represents a second and complementary theological root in addition to that already identified in Israel's covenant faith. More precisely, to what extent is Genesis 1-3 foundational for wisdom literature?

Proverbs In the book of Proverbs, in addition to individual proverbs which speak of God as creator (e.g., 14:31; $17: 5 ; 20: 12 ; 22: 2 ; 29: 13)$, one should note the image of the 'tree of

${ }^{81}$ Important contribution since Zimmerli include H.-J. Hermisson, 'Observations on the Creation Theology in Wisdom' in J.G. Gammie, et al., (eds.), Israelite Wisdom: Theological and Literary Essays in Honor of Samuel Terrien (Missoula: Scholars Press, 1978) 43-57; and Murphy, 'Wisdom and Creation', JBL 104 (1985) 3-11. Recently, P. Doll, Menschenschöpfung und Weltschöpfung in der alttestamentlichen Weisheit (SBS 117; Stuttgart: Katholisches Bibelwerk, 1985) especially 58; Boström, The God of the Sages, 80-89, and Hausmann, Studien zum Menschenbild, 254-55, have argued that explicit references to creation within the wisdom corpus are too infrequent, especially in Proverbs, to conclude that creation is the theological centre of wisdom. 
life' $(3: 18 ; 11: 30 ; 13: 12 ; 15: 4)$ which is drawn from Genesis 2:9. More significant is the brief comment in 3:19-20 that God established the world through wisdom (בחכמה) which is expanded upon in 8:22-31 in the midst of Lady Wisdom's final self-recommendation. However, this is not simply a poetic creation account in the service of wisdom theology: two students of Janowski have demonstrated convincingly that Proverbs 8 is a 'poetic paraphrase' or 'development' (Fortschreibung) of Genesis 1.82 In Proverbs 8, as in the Genesis 1 , the creation of human beings marks the climax and purpose of God's creative acts. That wisdom delights in humanity (8:31) is reason enough for humanity to delight in wisdom.

Ecclesiastes According to Hertzberg, the author of Ecclesiastes wrote with Genesis 1-4 before him; his view of life has been shaped by the creation account. 83 Clemens goes a step further in a recent article, claiming that Ecclesiastes is 'best understood as an arresting but thoroughly orthodox exposition of Genesis 1-3', noting a plethora of key words which recur in both texts. ${ }^{84}$ Against such a textual backdrop, an assessment of work as 'toil' (עמל) and life as 'ephemeral' (הבל, possibly a word-play on the name of the first to die, Abel) is not inconsistent with a call to enjoy the every-day gifts of the Creator which are 'very good' even in a fallen world. Ecclesiastes 3:11 ('He has made everything beautiful in its time') may well allude to this divine assessment, but 3:20b ('all come from dust, and to dust all return') is virtually identical to Genesis 3:19 (cf. Ec. 12:7 and 5:15[16], also Gn. 2:7 with Ec. 3:19). Ecclesiastes 7:29, which concludes Qoheleth's discourse on the limitations of righteousness and wisdom (7:15-29: 'This only have I found: God made mankind upright, but men have gone

82M. Bauks und G. Baumann, 'Im Anfang war...? Gen 1,1ff und Prov 8,2231 im Vergleich', BN 71 (1994) 24-52, a thesis already suggested by $M$. Jastrow, Hebrew and Babylonian Traditions (New York: 1914) 125.

${ }^{83}$ H.W. Hertzberg, Der Prediger (Gütersloh: Mohn, 1963), 230; see also C.C. Forman, 'Koheleth's Use of Genesis', JSS 5 (1960) 256-63. T.A. Perry's claim, (Dialogues with Kohelet. The Book of Ecclesiastes [University Park: Pennsylvania State UP, 1993], 24-25) that Qoheleth presented an 'AntiGenesis' is based on his negative interpretation of the book.

${ }^{84}$ D.M. Clemens, 'The law of sin and death: Ecclesiastes and Genesis 1-3', Themelios 19 (1994) 5. 
in search of many schemes') also may allude to Genesis 3. In other words, all that is good and all that is bad in Qoheleth's world can be traced to the events of Genesis 1-4; his challenge is how to live in such a world.

Job Although several sections of Job draw on creation motifs, the creation imagery is most prominent in the divine speeches in chs. 38-40. Here texts other than Genesis 1-2 present the closest parallels. Especially striking is the unusual use of the word in Job 38:10-11, 33 for setting nature's 'boundaries', (cf. Pr. 8:29; Je. 5:22; Ps. 148:6; also Je. 33:25). The Chaoskampf language of Job $7: 12 ; 9: 8,13 ; 26: 5-14$ (cf. 3:8 and ch. 41) has parallels in Psalm 74:12-14 as well as in Isaiah 27:1 and 51:9.

Though the creation theme is not referred to frequently in the Old Testament wisdom corpus, its use is significant: in Proverbs 1-9, in presenting the case for the primacy of wisdom, in Ecclesiastes, in portraying the world in which one must seek joy under the shadow of fading achievements and irresolvable conundrums, in Job, in proclaiming the utter sovereignty of the Creator who does not need to explain his actions. Especially in its obvious intertextual relationship to Genesis 1-4, wisdom's creation roots are apparent.

\section{Conclusion.}

What is the value of digging around in the canonical garden, seeking to expose wisdom's theological roots? Are these two roots, covenant and creation, intertwined? Several recent proposals for constructing Old Testament theology incorporate wisdom within one pole of a dialectical relationship, with redemption, history, the unique, the national, the mighty acts of God, being paired (and implicitly contrasted) with blessing, creation, the regular, the universal, man's response. 85 However, what we have sought to demonstrate in this section is that the Old Testament wisdom literature partakes in elements of both poles.

${ }^{85} \mathrm{~W}$. Brueggemann, 'A Convergence in Recent Old Testament Theologies', JSOT 18 (1980) 2-18. 
Throughout the Old Testament canon, creation and redemption are not separated, as independent traditions, but frequently and naturally linked. The toledoth formula of Genesis 2:4 integrally connects the account of the creation of the universe with the account of the election of a covenant family, and, as this family grows into a nation, the creation language of Genesis 1:28 is echoed in Exodus 1:7. Psalm 19 pointedly presents the complementary nature of revelation through creation (vv. 1-6) and revelation through the law (vv. 7-14). The God of creation is also the God who rules over the nations and redeems his people (Pss. 93, 95, 96). God's power as creator guarantees his power to judge and deliver ( $c f$. Amos' doxologies: 4:13; 5:8-9; 9:5-6; also Is. 40). Prophetic images of creation merge with images of redemption (Is. 51:9-11); the eschatological vision of restoration encompasses both a new heaven and new earth in which there will be both a return to Eden and a termination of the covenant curses (Is. 65:17-25). Through redemption, the creation purposes of God again will be realised, fellowship between God and his creation will be restored, and his image-bearers will be renewed according to the image of Jesus Christ, 'in whom are hidden all the treasures of wisdom and knowledge' (Col. 2:3).

Without seeking to expound or deny the unique contours or contribution of wisdom theology, we would like to propose another way to integrate it into Old Testament theology. In examining the theological roots from which it draws sustenance, we have argued against viewing wisdom as an independent tradition. How can Old Testament wisdom literature stand alone, despite its striking Ancient Near Eastern parallels, when it is upheld by the twin pillars which support the entire Old Testament canon: creation and covenant? 